\title{
Factors Affecting the Adoption of Self-Service Technology (SST) in the Public Sector:
}

\section{An Empirical Examination of Housing Corporations}

Guido Ongena, HU University of Applied Sciences, Utrecht, The Netherlands

iD https://orcid.org/0000-0002-3699-7178

Sanne Staat, Trivire Foundation, The Netherlands

Pascal Ravesteijn, HU University of Applied Sciences Utrecht, The Netherlands

\section{ABSTRACT}

In the Netherlands, housing corporations are increasingly adopting self-service technologies (SSTs) to support affairs their tenants need to arrange. The purpose of the study is to examine the customers' motivations of using SSTs in the context of the Dutch public housing sector. An empirical investigation is presented based on a sample of 1,209 tenants. Using partial least squares (PLS), the acceptance model of Blut, Wang, and Schoefer is adopted and tested. The results show that especially the need for interaction negatively influence the adoption of SSTs by tenants. Positively, subjective norm and self-efficacy influence the adoption. Furthermore, playfulness negatively influences this adoption. Developers of SSTs should focus on its ulitalitarian function, rather then invest in its playfulness. Moreover, adoption is propelled by the encouragement of others. This can be enhanced by positive word-ofmouth and should therefore stimulated.

\section{KEYWORDS}

Adoption Self-Service, Empirical Examination, Housing Corporations, Public Sector, Self-Service, Self-Service Technology, SST, Technology Adoption 


\section{INTRODUCTION}

Although e-government services tend to boost public value (Valle-Cruz, 2019), there is a lack of dissemination of these type of (Lopes, Macadar, \& Luciano, 2019). This study focuses on a specific type of e-service, namely self-service technology (SST). Moreover, it examines this technology in a specific public sector, the housing sector. Investments in enabling technology-based self-service has risen in the public housing sector (Veuger \& Chafia, 2018). Housing corporations have enthusiastically adopted self-service technologies (SSTs) to support various types of (Roach \& Beddeau, 2015). For instance, when scheduling a repair request or cancellation of the rental agreement, SSTs serve as an alternative or replacement for personal contact by phone or at the counter. In general, the benefits of the adoption of SSTs include labor cost reduction over time (Chang \& Yang, 2008) and improvement in consumer service and operational efficiency (Curran \& Meuter, 2005). Despite the increasing investments and ambitions, the housing sector remains lacking behind in the penetration of SSTs and its usage by the tenants (Veuger \& Chafia, 2018).

Hitherto, empirical research on the adoption of SSTs has primarily focused on SSTs in the airline industry (Chang \& Yang, 2008), the banking sector (Proença \& Antónia Rodrigues, 2011), the retail context (Weijters, Rangarajan, Falk, \& Schillewaert, 2007; Wang M., 2012; Demoulin \& Djelassi, 2016), and the hotel industry (Oh, Jeong, \& Baloglu, 2013). Motivations by the customers of housing corporations could however differ from customers in these contexts, specially as tenants of housing corporations tend to be lower income groups with also a lower educational level. Veuger \& Chafia (2018) already indicated a difference in behavior with regard to digital services when municipalities are compared to banks. This is supported by Kaushik, Agrawal and Rahman (2015) who found different attitudes of customers towards different SSTs. Moreover, these studies are conducted in contexts that already have a strong selfservice penetration. The self-service concept is still in its infancy in the housing sector. Against this background, the objective of the present study is to explore the customers' motivations of using SSTs in the context of the Dutch public housing sector. Subsequently, the following research question is formulated:

$R Q:$ What factors could affect the adoption of self-service technology (SST) by tenants in the context of the Dutch public housing sector?

This research pursues this question by utilizing the rigorous model of acceptance of SSTs developed through a meta-analysis (Blut, Wang, \& Schoefer, 2016) and applying it in the context of the Dutch public housing sector. An empirical examination among 1209 tenants of four housing associations is conducted. This study aims to provide managers and policymakers with insights into how to address customer satisfaction and usage behavior with self-service technology.

The remainder of this paper is organized as follows, the next section presents the literature and conceptual framework for the study, including the development of 
hypotheses. The third section describes the methodology of the empirical study. The results are presented in the fourth section. The fifth section discusses the findings in the context of the extant literature. The paper concludes with a summary of the major findings, the managerial implications, and the limitations of the study.

\section{CONCEPTUAL FRAMEWORK}

This research adopts the model as proposed by Blut, Wang, \& Schoefer (2016) to serve as a foundation in order to investigate acceptance of different SST types. Blut et al. (2016) conducted a meta-analysis of the factors that influence customer acceptance of SSTs. Their model is based on several acceptance models including the Technology Acceptance Model (TAM; Davis, Bagozzi, \& Warshaw, 1989) and the Unified Theory of Acceptance and Use of Technology (UTAUT; Venkatesh, Thong, \& Xu, 2012). The conceptual framework of this study is illustrated in Figure 1.

As is shown, the model consists of three different parts: (1) potential determinants of SST use, (2) mediators and (3) the outcome in relation to the intended use of SST. Studying behavioral intention as an indicator of user acceptance is in line with previous studies (e.g. Wang, 2012). The relationship between intention to use and actual usage is well supported in prior literature (e.g. Chin \& Lin, 2016). Perceived ease of use and perceived usefulness are two key variables that service as mediator. When considering the context of SST, perceived usefulness refers to an individual's concerns about using SST to complete his/her needs in regards to service transactions in a timely and efficient

Figure 1. Self-service technology acceptance framework based on the work of Blut, Wang, \& Schoefer (2016)

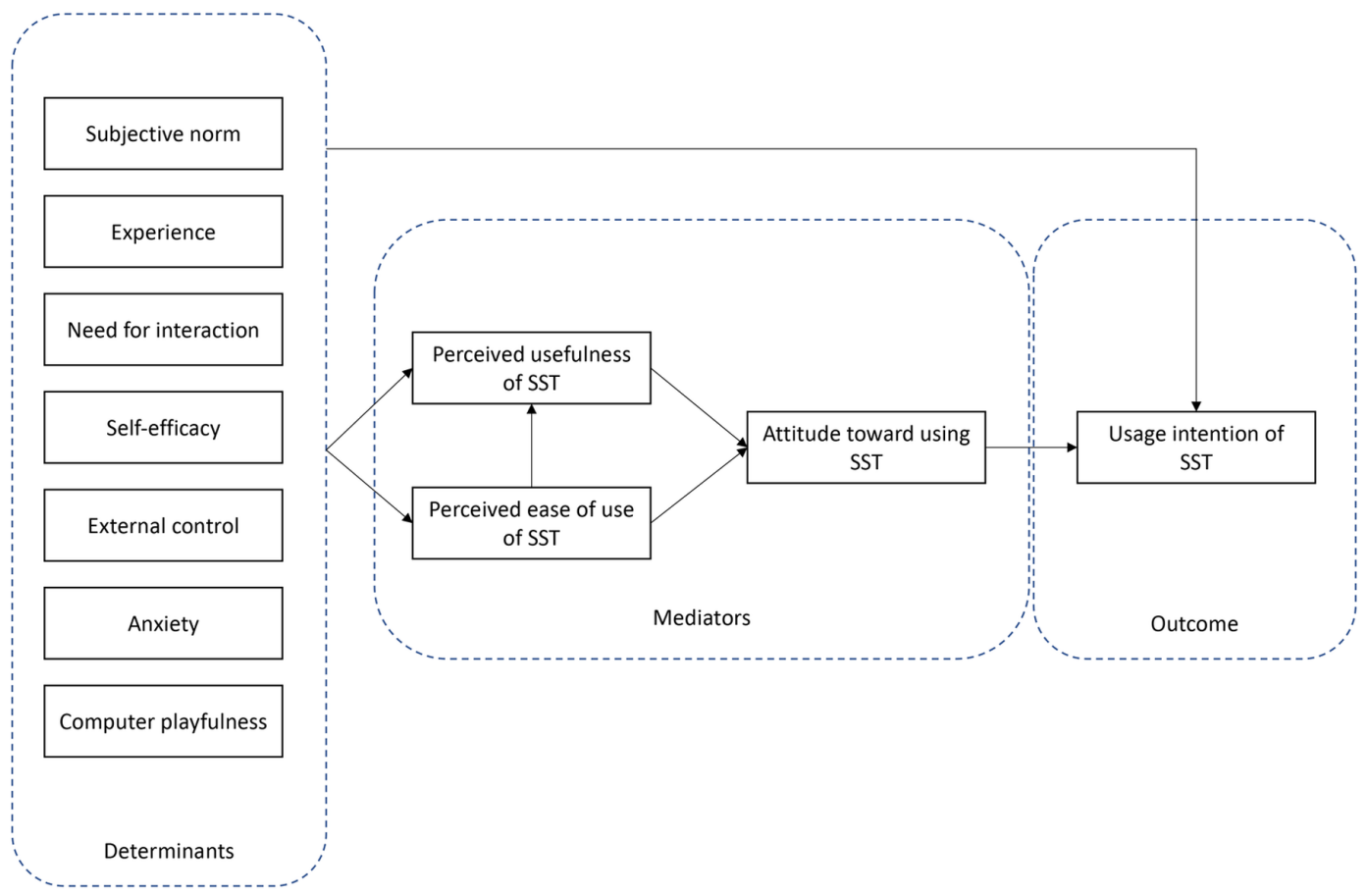


manner (Weijters, Rangarajan, Falk, \& Schillewaert, 2007). Perceived ease of use on the other hand refers to how the individual perceives the time and effort he/she spends to obtain the service through the use of a self-service technology (Berry, Seiders, \& Grewal, 2002). Also attitude toward use is included, as proposed in the original TAM (Davis, Bagozzi, \& Warshaw, 1989). The relationships among these three are well established and supported by an extensive amount of scientific literature (e.g. Chin $\&$ Lin, 2016), therefor the focus of our study is not on the rigour of the model itself but on the applicability of SSTs by the public housing sector.

Determinants in the framework have a multitude of theoretical roots. Subjective norm is introduced by Fishbein and Ajzen (Fishbein \& Ajzen, 1975) from rational behavioural theory. It refers to people's expectations regarding the performance of a particular behaviour. In the context of SST research found a key role of this factor in the acceptance of an SST (Kaushik, Agrawal, \& Rahman, 2015; Demoulin \& Djelassi, 2016). Experience is rooted in the UTAUT model and refers to the general experience customers have with technology. Meuter, Bitner, Ostrom and Brown (2005) found this to be an antecedent in the acceptance of SSTs.

The need for interaction, the desire to retain personal contact with others during a service encounter, is often found to negatively impact the use of SSTs (e.g. Meuter, Bitner, Ostrom, \& Brown, 2005; Demoulin \& Djelassi, 2016). Veuger \& Chafia (2018) also suggest this is a determinant for underutilizing SSTs in public housing associations. Self-efficacy is considered a key cognitive determinant of human behaviour. Studies also found this to affect a customer's intention to continue using an SST (Wang, Harris, \& Patterson, 2013; Demoulin \& Djelassi, 2016). While selfefficacy is related to internal control, external control is about the customer's belief regarding the availability of organizational resources and support structure to facilitate the use of the technology (Venkatesh \& Bala, 2008). It is also found to play a role in the intention to use an SST (Demoulin \& Djelassi, 2016). Anxiety for technology is an individual's apprehension, or even fear, of using, or simply considering using, technology in general. Research showed that this play(Meuter, Ostrom, Bitner, \& Roundtree, 2003; Demoulin \& Djelassi, 2016). Fun, excitement, joy, pleasure and contentment are terms associated with computer playfulness. With the seminal work of Van der Heijden (2004) enjoyment is an integral part of acceptance models. It is therefore not suprising that studies on SST acceptance also found significant results in this context (e.g. Wang, Harris, \& Patterson, 2013).

\section{RESEARCH METHOD}

This study scrutinizes individual motivations and behavior. It is rather common for this unit of analysis to adopt a quantitative method (Groeneveld, Tummers, Bronkhorst, Ashikali, \& Thiel, 2015). A cross-sectional questionnaire is thus used for the analysis of the usage of SSTs. 


\subsection{Measures}

The questionnaire was planned to be as short as possible and easy to complete. Before collecting data, the survey was pre-tested with 10 tenants and experts to clarify whether the questions were understandable and correctly interpreted. The questionnaire contains several constructs and uses both multi-item measurement and single-item measures. Although multi-item measurement is common practice in prior self-service technology adoption studies (e.g. Curran \& Meuter, 2005), single-item measures are also found to be valid when examining technology usage (Rossiter \& Braithwaite, 2013). This is supported by Cheah, Sarstedt, Ringle, Ramayah, and Ting (2018), who found only marginal differences between single and multi-items in the context of hospitality in terms of convergent validity and recommended on short single items in order to minimize survey length. Especially when the constructs are concrete, single-items increase the response rate, and have a closer linkage between academic rigor and practical realities (Nair, Ataseven, Habermann, \& Dreyfus, 2016).

The constructs that are measured by single items include self-efficacy, computer playfulness, experience, subjective norm, attitude and behavioral intention. The constructs that are measured with multiple items are anxiety, need for interaction, external control, perceived usefulness and perceived ease of use. All the measurement items were measured using a five-point Likert scale ranging from " $1=$ strongly disagree" to " $5=$ strongly agree". Both type of measures, single items and multiple items, were adopted from the extensive work done by Blut, Wang and Schoefer (2016).

\subsection{Data Collection and Sample}

The Netherlands has 339 housing corporations with more than 2 million houses in their portfolio. The Netherlands has the highest percentage of social housing (35\%) in the European Union (Van der Veer \& Schuiling, 2005). Data was collected from tenants at four housing corporations in the Netherlands in 2019. These corporations primarily operate in the west of the Netherlands. Three of these are considered large (between 10.000 and 25.000 rentable units) and one extra large ( $>25.000$ rentable units).

Two housing corporations shared the survey via their online channels (website and Facebook). The other two corporations send the survey via a research agency to a select part of their tenant base. Criteria for this selection entailed that the email adress was known, and that they were registrered for the customer panel. This resulted in 1570 respondents that started the online questionnaire, of which 1209 were fully completed. Only the latter are used for further analyses.

The socio-demographic characteristics are shown in Table 1. In the sample, the ratio of men to women was approximately equal $(45.4 \%$ vs. $54.6 \%)$. The majority of the sample ( $>60 \%$ ) were above the age of 60 . The sample is thus somewhat skewed to older people. With regard to the educational level of the respondents, the descriptive figures show the majority of the sample has at least their high school diploma. 


\section{RESULTS}

Partial least squares (PLS) is used to test the model. This is used because the research presented in this study can be characterized as exploratory as it aims to identify key 'driver' constructs rather than theory testing or comparison. Also, PLS makes less demand on measurement scales (Gefen, Straub, \& Boudreau, 2000; Hair, Ringle, \& Sarstedt, 2011) and normal distribution (Chin, 1998). Using the software SmartPLS (Ringle, Wende, \& Becker, 2015), the measurement model is examined to assess reliability and validity before testing the structural model and thus test the hypotheses.

\subsection{Measurement Model}

First, the reliability of the multi-item measures is assessed. The Cronbach's alpha values are between 0.801 and 0.916 , the composite reliabilities of multi-item scales modelled with reflective indicators are 0.70 or greater, suggesting that the scales have a high level of internal consistency reliability (Hair, Black, Babin, Anderson, \& Tatham, 2009). The values of $\rho \mathrm{A}$ are also acceptable as they are above 0.70 (Henseler, Hubona, \& Ray, 2016). Second, convergent validity of the constructs is assessed. As shown in Table 2 the figures also demonstrate sufficient results as the average variance extracted (AVE) are at least 0.50 (Fornell \& Larcker, 1981).

Thirdly, to assess discriminant validity the Fornell-Larcker criterion (Fornell \& Cha, 1994) is examined. A latent construct should better explain the variance of its own indicator rather than the variance of other latent constructs. Therefore, the square root of each construct's AVE should have a greater value than the correlations with other latent constructs. Table 3 provides the results for our study and shows that the criterion holds for every construct.

Additionally, following the latest guidelines, the heterotrait-monotrait ratio of correlations (HTMT) is also used to assess discriminant validity. Henseler Ringle and Sarstedt (2015) argued a strong case of using this approach. The authors also showed poor performance of cross-loadings in measurement models and thus this is left out of this study. In order to clearly discriminate between two factors, the HTMT should be smaller than 0.90 (Henseler, Hubona, \& Ray, 2016). As Table 4 shows, all correlations comply to that criterion. Hence, discriminant validity is demonstrated by the Fornell-Larcker criterion and the heterotrait-monotrait ratio.

To test for multicollinearity, the variance inflation factors (VIFs) were computed (Kock, 2015). All were found to be less than the conservative threshold of 5 with a minimal value of 1.32 and a maximum value of 3.76, thus suggesting that multicollinearity was not a major issue in the study.

\subsection{Structural Model}

Before discussing the path coefficients, the endogenous latent variable's coefficients of determination $\left(R^{2}\right)$ and the blindfolding-based cross validated redundancy measure $Q^{2}$ are examined. These are shown in Table 5. Using the guidelines of Henseler, Ringle and Sinkovics (2009) one can state that the $R^{2}$ of perceived usefulness and usage intention indicate a moderate level of explanatory power. The $R^{2}$ of perceived 
Table 1. Descriptive statistics of sample characteristics $(\mathrm{N}=1209)$

\begin{tabular}{|l|l|l|}
\hline \multicolumn{1}{|c|}{ Frequency } & \multicolumn{1}{c|}{ Percentage } \\
\hline Gender & & \\
\hline Male & 549 & $45.4 \%$ \\
\hline Female & 660 & $54.6 \%$ \\
\hline Age & & \\
\hline $18-29$ & 37 & $3.1 \%$ \\
\hline $30-39$ & 90 & $7.4 \%$ \\
\hline $40-49$ & 104 & $8.6 \%$ \\
\hline $50-59$ & 235 & $19.4 \%$ \\
\hline $60-69$ & 304 & $25.1 \%$ \\
\hline $70-79$ & 309 & $25.6 \%$ \\
\hline$>80$ & 130 & $10.8 \%$ \\
\hline Education & & $11.3 \%$ \\
\hline Less than high school degree & 99 & $8.2 \%$ \\
\hline High school degree or equivalent & 744 & $61.5 \%$ \\
\hline Higher education & 229 & $18.9 \%$ \\
\hline Other & 137 & \\
\hline
\end{tabular}

Table 2. Cronbach's alpha, composite reliabilities and average variance Extracted (AVE)

\begin{tabular}{|l|l|l|l|l|}
\hline & \multicolumn{1}{|c|}{$\begin{array}{c}\text { Cronbach's } \\
\text { Alpha }\end{array}$} & \multicolumn{1}{|c|}{$\boldsymbol{\rho A}$} & \multicolumn{1}{c|}{$\begin{array}{c}\text { Composite } \\
\text { Reliability }\end{array}$} & \multicolumn{1}{|c|}{ AVE } \\
\hline External control & 0.801 & 0.838 & 0.881 & 0.712 \\
\hline Need for interaction & 0.815 & 0.848 & 0.878 & 0.645 \\
\hline Anxiety & 0.870 & 0.872 & 0.911 & 0.721 \\
\hline Perceived Ease of Use & 0.884 & 0.889 & 0.915 & 0.685 \\
\hline Perceived Usefulness & 0.916 & 0.918 & 0.934 & 0.704 \\
\hline
\end{tabular}

ease of use on the other hand indicate a substantial level of explanatory power. The results show that the three dependent variables have a $Q^{2}$ less than 0.50 , which depicts medium predictive accuracy.

The determinants show different results with regard to the mediators (usefulness and ease of use). Perceived usefulness is significantly positively affected by subjective norm $(\beta=0.132 ; p<0.05)$, experience $(\beta=0.050 ; p<0.05)$, external control $(\beta=$ $0.176 ; p<0.05)$ and anxiety $(\beta=0.074 ; p<0.05)$, and negatively affected by the need for interaction $(\beta=0.181 ; p<0.05)$ and computer playfulness $(\beta=-0.058 ; p$ $<0.05)$. Perceived ease of use is positively affected by self-efficacy $(\beta=0.287 ; p<$ $0.05)$ and external control $(\beta=0.087 ; p<0.05)$ and negatively affected by the need 
Table 3. Correlations (off-diagonal elements) and square root of the AVEs (diagonal elements)

\begin{tabular}{|c|c|c|c|c|c|}
\hline & $\begin{array}{c}\text { External } \\
\text { control }\end{array}$ & $\begin{array}{c}\text { Need for } \\
\text { interaction }\end{array}$ & Anxiety & $\begin{array}{c}\text { Perceived } \\
\text { Ease of Use }\end{array}$ & $\begin{array}{c}\text { Perceived } \\
\text { Usefulness }\end{array}$ \\
\hline External control & 0.844 & & & & \\
\hline Need for interaction & -0.258 & 0.803 & & & \\
\hline Anxiety & -0.281 & 0.492 & 0.849 & & \\
\hline Perceived Ease of Use & 0.388 & -0.592 & -0.767 & 0.828 & \\
\hline Perceived Usefulness & 0.456 & -0.540 & -0.520 & 0.693 & 0.839 \\
\hline
\end{tabular}

Table 4. Heterotrait-monotrait ratio of correlations (HTMT)

\begin{tabular}{|l|l|l|l|l|}
\hline & External control & \multicolumn{1}{|c|}{$\begin{array}{c}\text { Need for } \\
\text { interaction }\end{array}$} & Anxiety & $\begin{array}{c}\text { Perceived Ease } \\
\text { of Use }\end{array}$ \\
\hline Need for interaction & 0.302 & & & \\
\hline Anxiety & 0.317 & 0.561 & & \\
\hline Perceived Ease of Use & 0.442 & 0.673 & 0.875 & 0.761 \\
\hline Perceived Usefulness & 0.521 & 0.609 & 0.583 & \\
\hline
\end{tabular}

Table 5. Results of structural equation model

\begin{tabular}{|l|l|l|l|}
\hline \multicolumn{1}{|c|}{ Determinant } & \multicolumn{1}{|c|}{ Perceived usefulness } & \multicolumn{1}{c|}{ Perceived ease of use } & \multicolumn{1}{c|}{ Usage intention } \\
\hline Subjective norm & $0.132^{*}$ & 0.024 & $0.106^{*}$ \\
\hline Experience & $0.050^{*}$ & 0.025 & 0.005 \\
\hline Need for interaction & $-0.181^{*}$ & $-0.198^{*}$ & $-0.244^{*}$ \\
\hline Self-efficacy & 0.040 & $0.287^{*}$ & $0.158^{*}$ \\
\hline External control & $0.176^{*}$ & $0.087^{*}$ & 0.045 \\
\hline Anxiety & $0.074^{*}$ & $-0.406^{*}$ & -0.056 \\
\hline Computer playfulness & $-0.058^{*}$ & $-0.050^{*}$ & $-0.069^{*}$ \\
\hline$R^{2}$ & 0.57 & 0.72 & 0.45 \\
\hline$Q^{2}$ & 0.37 & 0.46 & 0.43 \\
\hline
\end{tabular}

${ }^{*} p<.05$.

for interaction $(\beta=-0.181 ; p<0.05)$, anxiety $(\beta=-0.406 ; p<0.05)$ and computer playfulness $(\beta=-0.050 ; p<0.05)$.

\section{DISCUSSION AND CONCLUSION}

This explanatory study aimed at investigating the impact of positive and negative determinants on use of self-service technology by public housing corporations in the Netherlands. In addition, the examination of the mediating role of perceived usefulness and perceived ease of use was considered. The results, with 1209 respondents, 
revealed empirical evidence for a major part of the determinants and mediators in the conceptual model.

Encouragement by others, subjective norm, is influencing the SST's perceived usefulness. This also implies that when tenants communicate, they tend to discuss the functionalities of the SST rather than its ease of use. Moreover, it directly affects the intention to use the SST. Prior research found that a positive word-of-mouth influences the intention to use banking self-service technology (Proença \& Antónia Rodrigues, 2011). This study's findings show that this also holds for SSTs in the public housing sector.

Second, experience with the SST influences its usefulness as perceived by the user. Tenants perceptions about the utilitarian benefits of an SST is thus increased when they use it more often. This is in line with research on technology acceptance by consumers (Venkatesh, Thong, \& Xu, 2012). It however does not influence the intention to use the SST. Interestingly, this differs from prior SST acceptance research (e.g. Blut, Wang, \& Schoefer, 2016). A possible explanation of this divergent result is the low frequency of usage by tenants. For instance, online banking technology or pump terminals are used on a daily or weekly basis (Meuter, Ostrom, Bitner, \& Roundtree, 2003), whereas SST in the public housing sector is typically used on a limited basis.

Thirdly, the need for interaction shows an overall significant impact. This empirically confirms the suggestion by Veuger \& Chafia (2018) that tenants need this interaction. Moreover, it plays a key role for underutilizing SSTs in public housing associations as it indicates a very strong negative effect on its usefulness, ease of and the intention to use an SST. Tenants thus tend to prefer face-to-face contact regarding service issues with their housing. This conclusion must be interpreted in the light of socio-demographic characteristics as the sample is skewed towards older people. Prior research found that age has a strong and direct negative effect on preference for SST over personnel-in-contact (Simon \& Usunier, 2007), this is also confirmed in this research.

Both internal (self-efficacy) and external control play a significant role in affecting the perception of the convenience of the SST. Especially self-efficacy highly impacts how easily the SST is operated. This can be explained by the fact that SSTs by public housing associations are primarily characterized by its utilitarian features. Selfefficacy, similar to experience, is more relevant for utilitarian SSTs. For utilitarian SSTs, customers are more willing to put in more effort themselves (Blut, Wang, \& Schoefer, 2016). This can also explain that external control does not affect the intention to use the SSTs offered by public housing associations.

The penultimate determinant, anxiety, does not affect the intention to use directly. However, it does play a significant role in influencing the perceptions about the usability of the service. Tenants that have a high anxiety level seem to contemplate the ease of use.

Lastly, computer playfulness was found to negatively influence the mediating variables as well as the intention to use the SST. This is the most prevalent outing of the utilitarian role of SSTs in public housing. Even more, signs of enjoyment are 
irrelevant when using these technologies. This in contrast to other sectors such as retail, where enjoyment of SSTs has a significant effect on its consumer satisfaction (Wang M., 2012).

\subsection{Managerial Implications}

Given that SST involves significant financial investment and that tenants are increasingly interacting with public housing associations through such technologies, the present study has implications for managers of such services. First, a major influence on the adoption is the lack of interaction in these technologies. Managers must reflect on the importance of human contact in relation to their services. The possibility to communicate face-to-face with a person during the use of an SST is advisable. Still, managers who are in charge of SST may also need to consider embedding conversational interfaces (e.g. chatbots) in order to increase the feeling of interaction. The causal link that exists between consumers' perceptions of control and the dependent variables suggests that enhancing consumers' perceptions of control is essential. Managers can help their consumers to enhance their feeling of control by minimizing uncertainty during the service delivery process. By means of, for instance, a video tutorial on the SST screen that gives clear, step-by-step descriptions of the service process or providing an intuitive operating interface for the SST. Finally, when developing SST, one should include tenants in this process. Tenants should be consulted and involved in the design of the SST to ensure that it addresses important needs. Especially nonfunctional requirements. This will decrease anxiety and increase a positive word-ofmouth, which in turn increases the adoption as this is influenced by subjective norm.

\subsection{Limitations and Future Research}

This research has some acknowledged limitations. First, it must be stipulated that this study is conducted in the Dutch context. The public housing sector is far less globalized then others. The results should therefore be generalized with caution. Second, the questionnaire of this study was distributed via online channels. People with no internet access were thus not considered. Future research can broaden the sample by identifying and including this specific group of tenants. Third, in contrast to other studies, this study used some single-item variables. Although literature is indecisive, it is common practice to use multi-item variables. Future research therefore can include multi-item variables to increase the reliability of the model. Fourth, the intention to use the SST is measured in this study. Although much prior research showed a clear relation between the intention and actual usage, research can be enriched by studying its actual usage as well as measuring the continued use of SST over time. 


\section{REFERENCES}

Berry, L., Seiders, K., \& Grewal, D. (2002). Understanding service convenience. Journal of Marketing, 66(3), 1-17. doi:10.1509/jmkg.66.3.1.18505

Blut, M., Wang, C., \& Schoefer, K. (2016). Factors Influencing the Acceptance of Self-Service Technologies: A Meta-Analysis. Journal of Service Research, 19(4), 396-416. doi:10.1177/1094670516662352

Chang, H., \& Yang, C. (2008). Do airline self-service check-in kiosks meet the needs of passengers? Tourism Management, 29(5), 980-993. doi:10.1016/j.tourman.2007.12.002

Cheah, J., Sarstedt, M., Ringle, C., Ramayah, T., \& Ting, H. (2018). Convergent validity assessment of formatively measured constructs in PLS-SEM: On using single-item versus multi-item measures in redundancy analyses. International Journal of Contemporary Hospitality Management, 30(11), 3192-3210. doi:10.1108/ IJCHM-10-2017-0649

Chin, J., \& Lin, S. (2016). A Behavioral Model of Managerial Perspectives Regarding Technology Acceptance in Building Energy Management Systems. Sustainability, 8(7), 641. doi:10.3390/su8070641

Chin, W. (1998). The partial least squares approach to structural equation modeling. In G. Marcoulides (Ed.), Modern Methods for Business Research (pp. 1295-1336). Lawrence Erlbaum Associates.

Curran, J., \& Meuter, M. (2005). Self-service technology adoption: Comparing three technologies. Journal of Services Marketing, 19(2), 103-113. doi:10.1108/08876040510591411

Davis, F., Bagozzi, R., \& Warshaw, P. (1989). User Acceptance of Computer Technology: A Comparison of Two Theoretical Models. Management Science, 35(8), 982-1003. doi:10.1287/mnsc.35.8.982

Demoulin, N., \& Djelassi, S. (2016). An integrated model of self-service technology (SST) usage in a retail context. International Journal of Retail \& Distribution Management, 44(5), 540-559. doi:10.1108/IJRDM-08-2015-0122

Fishbein, M., \& Ajzen, I. (1975). Belief, Attitude, Intention, and Behavior: An Introduction to Theory and Research. Addison-Wesley.

Fornell, C., \& Cha, J. (1994). Partial least squares. Advanced Methods of Marketing Research, 407, 52-78.

Fornell, C., \& Larcker, D. (1981). Evaluating structural equation models with unobservable measurement error. JMR, Journal of Marketing Research, 18(1), 39-50. doi:10.1177/002224378101800104

Gefen, D., Straub, D., \& Boudreau, M. (2000). Structural equation modeling techniques and regression: Guidelines for research practice. Communications of AIS, 4(7), 1-77. 
Groeneveld, S., Tummers, L., Bronkhorst, B., Ashikali, T., \& Thiel, S. (2015). Quantitative Methods in Public Administration: Their Use and Development Through Time. International Public Management Journal, 18(1), 61-86. doi:10.1080/10967 494.2014.972484

Hair, J., Black, C., Babin, J., Anderson, R., \& Tatham, L. (2009). Multivariate data analysis (7th ed.). Prentice Hall.

Hair, J., Ringle, C., \& Sarstedt, M. (2011). PLS-SEM: Indeed a Silver Bullet. Journal of Marketing Theory and Practice, 19(2), 139-152. doi:10.2753/MTP1069-6679190202

Henseler, J., Hubona, G., \& Ray, P. (2016). Using PLS path modeling in new technology research: Updated guidelines. Industrial Management \& Data Systems, 116(1), 2-20. doi:10.1108/IMDS-09-2015-0382

Henseler, J., Ringle, C., \& Sinkovics, R. (2009). The use of partial least squares path modeling in international marketing. In R. Sinkovics \& P. Ghauri (Eds.), Advances in International Marketing (pp. 277-320). Emerald.

Henseler, J., Ringle, C. M., \& Sarstedt, M. (2015). A New Criterion for Assessing Discriminant Validity in Variance-based Structural Equation Modeling. Journal of the Academy of Marketing Science, 43(1), 115-135. doi:10.1007/s11747-014-0403-8

Kaushik, A., Agrawal, A., \& Rahman, Z. (2015). Tourist behaviour towards self-service hotel technology adoption: Trust and subjective norm as key antecedents. Tourism Management Perspectives, 16, 278-289. doi:10.1016/j.tmp.2015.09.002

Kock, N. (2015). Common method bias in PLS-SEM: A full collinearity assessment approach. International Journal of e-Collaboration, 11(4), 1-10. doi:10.4018/ ijec. 2015100101

Lopes, K., Macadar, M., \& Luciano, E. (2019). Key drivers for public value creation enhancing the adoption of electronic public services by citizens. International Journal of Public Sector Management, 32(5), 546-561. doi:10.1108/IJPSM-03-2018-0081

Meuter, M., Bitner, M., Ostrom, A., \& Brown, S. (2005). Choosing Among Alternative Service Delivery Modes: An Investigation of Customer Trial of Self-Service Technologies. Journal of Marketing, 69(2), 61-83. doi:10.1509/jmkg.69.2.61.60759

Meuter, M., Ostrom, A., Bitner, M., \& Roundtree, R. (2003). The influence of technology anxiety on consumer use and experiences with self-service technologies. Journal of Business Research, 56(11), 899-906. doi:10.1016/S0148-2963(01)00276-4

Nair, A., Ataseven, C., Habermann, M., \& Dreyfus, D. (2016). Toward a continuum of measurement scales in Just-in-Time (JIT) research - an examination of the predictive validity of single-item and multiple-item measures. Operations Management Research, 9(1-2), 35-48. doi:10.1007/s12063-016-0108-x

Oh, H., Jeong, M., \& Baloglu, S. (2013). Tourists' adoption of self-service technologies at resort hotels. Journal of Business Research, 66(6), 692-699. doi:10.1016/j. jbusres.2011.09.005 
Proença, J., \& Antónia Rodrigues, M. (2011). A comparison of users and non-users of banking self-service technology in Portugal. Managing Service Quality: An International Journal, 21(2), 192-210. doi:10.1108/09604521111113465

Ringle, C. M., Wende, S., \& Becker, J.-M. (2015). SmartPLS 3. Boenningstedt: SmartPLS GmbH. Opgehaald van http://www.smartpls.com

Roach, C., \& Beddeau, C. (2015). Engaging Citizens and Delivering Services: The Housing Corporation in Trinidad and Tobago. International Journal of Public Administration in the Digital Age, 2(3), 61-79. doi:10.4018/ijpada.2015070104

Rossiter, J., \& Braithwaite, B. (2013). C-OAR-SE-based single-item measures for the two-stage Technology Acceptance Model. Australasian Marketing Journal, 21(1), 30-35. doi:10.1016/j.ausmj.2012.08.005

Simon, F., \& Usunier, J.-C. (2007). Cognitive, demographic, and situational determinants of service customer preference for personnel-in-contact over selfservice technology. International Journal of Research in Marketing, 24(2), 163-173. doi:10.1016/j.ijresmar.2006.11.004

Valle-Cruz, D. (2019). Public value of e-government services through emerging technologies. International Journal of Public Sector Management, 32(5), 530-545. doi:10.1108/IJPSM-03-2018-0072

Van der Heijden, H. (2004). User Acceptance of Hedonic Information Systems. Management Information Systems Quarterly, 28(4), 695-704. doi:10.2307/25148660

Van der Veer, J., \& Schuiling, D. (2005). The Amsterdam housing market and the role of housing associations. Journal of Housing and the Built Environment, 20(2), 167-181. doi:10.1007/s10901-005-9004-7

Venkatesh, V., \& Bala, H. (2008). Technology Acceptance Model 3 and a research agenda on interventions. Decision Sciences, 39(2), 273-315. doi:10.1111/j.15405915.2008.00192.x

Venkatesh, V., Thong, J. L., \& Xu, X. (2012). Consumer Acceptance and Use of Information Technology: Extending the Unified Theory of Acceptance and Use of Technology. Management Information Systems Quarterly, 36(1), 157-178. doi:10.2307/41410412

Veuger, J., \& Chafia, K. (2018). Digitalisering dienstverlening corporatiesector: stand van zaken, verklaringen en mogelijkheden voor de toekomst [Dutch]. In 3rd Conference of Interdisciplinary Research on Real Estate (CIRRE) (pp. 434-439). Groningen: Hanze University of Applied Sciences.

Wang, C., Harris, J., \& Patterson, P. (2013). The Roles of Habit, Self-Efficacy, and Satisfaction in Driving Continued Use of Self-Service Technologies: A Longitudinal Study. Journal of Service Research, 16(3), 400-414. doi:10.1177/1094670512473200

Wang, M. (2012). Determinants and consequences of consumer satisfaction with selfservice technology in a retail setting. Managing Service Quality: An International Journal, 22(2), 128-144. doi:10.1108/09604521211218945 
Weijters, B., Rangarajan, D., Falk, T., \& Schillewaert, N. (2007). Determinants and Outcomes of Customers' Use of Self-Service Technology in a Retail Setting. Journal of Service Research, 10(1), 3-21. doi:10.1177/1094670507302990 
Guido Ongena (PhD) is an associate professor and program director at the Institute of ICT at HU University of Applied Sciences Utrecht in the Netherlands. $\mathrm{He}$ is experienced in developing, coordinating and teaching educational programmes in the field of data science. He is affiliated with the research group process innovation and information systems. His research has been published in journals such as Business Process Management Journal, Behaviour \& Information Technology, Telematics and Informatics, International Journal on Media Management, and Information Research: An International Electronic Journal. Guido obtained a PhD from the University of Twente, The Netherlands.

Sanne Staat (MSc) has completed the Master of informatics at the HU university of applied science in the Netherlands. From her position as an information management advisor at a housing association, she has experience in implementing self-service portals and is therefore interested in increasing the use among tenants.

Pascal Ravesteijn is professor of Process Innovation and Information Systems within the research center for Digital Business and Media at HU University of Applied Sciences Utrecht. Throughout his career he has always worked on the boundary between Business and IT. This is reflected in his current research interests and projects that mainly focus on IT-driven business \& process model innovation and the subsequent competences and skills that employees need to be effective in a digital environment. Pascal is a member of the board of directors of the International Information Management Association (IIMA) and the editor-in-chief of the International Journal of Information Technology and Management. 